\section{Mechanisms of Glucagon Secretion during Insulin-induced Hypoglycemia in Man \\ Role of the Beta Cell and Arterial Hyperinsulinemia}

\author{
Geremia Bolli, Pierpaolo De Feo, Gabriele Perriello, \\ Salvatore De Cosmo, Pietro Compagnucci, \\ Fausto Santeusanio, Paolo Brunetti, and Roger H. Unger \\ Istituto di Patologia Medica, Università di Perugia, \\ 06100 Perugia, Italy; Veterans Administration Medical Center \\ and University of Texas Southwestern Medical School, \\ Dallas, Texas 75235
}

A trolling the response of glucagon to hypoglycemia, a vital component of the counterregulatory hormonal response, the role of intraislet insulin was studied in seven normal subjects and five subjects with insulin-dependent diabetes mellitus (IDDM) (of $<15$-mo duration). In the normal subjects, hypoglycemia (arterial plasma glucose [PG] 53 \pm 3 $\mathrm{mg} / \mathrm{dl}$ ) induced by an intravenous insulin infusion (30 $\mathrm{mU} / \mathrm{m}^{2} \cdot \mathrm{min}$ for $1 \mathrm{~h}$, free immunoreactive insulin [FIRI] $58 \pm 2 \mu \mathrm{U} / \mathrm{ml}$ ) elicited a $100 \%$ fall in insulin secretion and an integrated rise in glucagon of $7.5 \mathrm{ng} / \mathrm{ml}$ per $120 \mathrm{~min}$. When endogenous insulin secretion was suppressed by $\simeq 50$ or $\simeq 85 \%$ by a hyperinsulinemic-euglycemic clamp (FIRI $63 \pm 1.5$ or $147 \pm 0.3 \mu \mathrm{U} / \mathrm{ml}$, respectively) before hypoglycemia, the alpha cell responses to hypoglycemia were identical to those of the control study. When the endogenous insulin secretion was stimulated by $\simeq 100 \%$ (hyperinsulinemic-hyperglycemic clamp, FIRI $145 \pm 1.5 \mu \mathrm{U} /$ $\mathrm{ml}, \mathrm{PG} 132 \pm 2 \mathrm{mg} / \mathrm{dl}$ ) before hypoglycemia, the alpha

This work was presented in part at the 40th Annual Meeting of the American Federation for Clinical Research, April 29-May 2, 1983, Washington, DC.

Dr. Bolli is the recipient of an International Research Fellowship from the Fogarty International Center (National Institutes of Health, 1F05 TW093229) at the Diabetes and Metabolism Laboratory, Endocrine Research Unit, Departments of Medicine and Physiology, Mayo Clinic and Medical School, Rochester, MN, and a grant from the Italian Diabetes Association. Address reprint requests to Dr. Bolli, Istituto dí Patologia Medica, Italy. 1983.

Received for publication 21 April 1983 and in revised form 28 October

The Journal of Clinical Investigation, Inc.

Volume 73, April 1984, 917-922 cell responses to the hypoglycemia were also superimposable on those of the control study.

Finally, in C-peptide negative diabetic subjects made euglycemic by a continuous overnight intravenous insulin infusion, the alpha cell responses to hypoglycemia were comparable to those of normal subjects despite absent beta cell secretion, and were not affected by antecedent hyperinsulinemia (hyperinsulinemic-euglycemic clamp for $2 \mathrm{~h}$, FIRI $61 \pm 2 \mu \mathrm{U} / \mathrm{ml}$ ).

These results indicate that the glucagon response to insulin-induced hypoglycemia is independent of the level of both endogenous intraislet and exogenous arterial insulin concentration in normal man, and that this response may be normal in the absence of endogenous insulin secretion, in contrast to earlier reports. Thus, loss of beta cell function is not responsible for alpha cell failure during insulin-induced hypoglycemia in IDDM.

\section{Introduction}

In man and in other mammals, glucagon is vital to the defense against hypoglycemia. Despite the array of other influences, i.e., hormonal, neural, and substrate influences upon glucose homeostasis (1), failure of glucagon to respond to a blood glucose decrement will impair counterregulation in both the postabsorptive state $(2,3)$ and after meal ingestion $(4,5)$. Indeed, type I diabetics with an obtunded glucagon response to hypoglycemia exhibit a defective defense against hypoglycemia (6), which has been implicated in the unexpected deaths recently encountered in meticulously controlled patients (7).

The etiology of the impaired glucagon response to hypoglycemia is unknown. An intrinsic loss of glucoreceptive capability by the diabetic alpha cell has been suggested (6). More recently, it has been proposed that insulin, a potent inhibitor of glucagon secretion (8), normally serves as a release-inhibiting factor for glucagon $(9,10)$, and that failure of the alpha cell 
response to hypoglycemia in human type I diabetes mellitus is due to a lack of disinhibition secondary to loss of beta cells (9). In this view, the beta cell is the principal glucose sensor of the islet and decrements in blood glucose stimulate the alpha cell by suppression of insulin secretion (9).

The present series of studies were undertaken to assess the extent to which the alpha cell function is dependent on the beta cell function during hypoglycemia in normal man, and whether loss of beta cells is responsible for alpha cell failure during hypoglycemia in type I diabetes mellitus.

\section{Methods}

Seven normal healthy volunteers within $10 \%$ of ideal body weight and five age- and weight-matched insulin-dependent diabetic subjects were studied after obtaining fully informed consent. The normal subjects, ranging in age from 19 to $35 \mathrm{yr}(26 \pm 3 \mathrm{yr}$, mean \pm SEM), had been on a weight-maintaining diet ( $300 \mathrm{~g}$ carbohydrate/d) for at least $1 \mathrm{wk}$ before all studies. The diabetic subjects had diabetes of 13-15 mo duration and were $C$-peptide deficient $(0.08 \pm 0.02 \mathrm{ng} / \mathrm{ml}$ before and $0.08 \pm 0.04$ $\mathrm{ng} / \mathrm{ml}$ after $1 \mathrm{mg}$ glucagon given intravenously).

Four studies were carried out in the normal subjects (studies I-IV) and two studies in the diabetic subjects (studies V-VI) at 4-6-d intervals. In study $I$, to assess the responses of alpha and beta cell during insulininduced hypoglycemia in normal subjects, insulin was infused intravenously at the rate of $30 \mathrm{mU} / \mathrm{m}^{2} \cdot \min$ for $1 \mathrm{~h}$. In study II, to assess the effects of insulin-mediated suppression of the beta cells on the alpha cell responses to hypoglycemia, insulin was infused at the rate of study I for $4 \mathrm{~h}$ (from -120 to $120 \mathrm{~min}$ ) together with glucose to clamp plasma glucose (PG) ${ }^{1}$ concentration at euglycemic levels during the initial $2 \mathrm{~h}$ (from -120 to 0 min) and at the PG values observed in study I (from 0 to $120 \mathrm{~min}$ ). In study III, to assess the effects of a further insulinmediated suppression of beta cells, insulin was infused at the rate of 60 $\mathrm{mU} / \mathrm{m}^{2} \cdot \min$ for $4 \mathrm{~h}$ (from -120 to $120 \mathrm{~min}$ ) together with glucose to clamp PG concentration as in study II. In study IV, to assess the effects of hyperglycemic stimulation of the beta cell, insulin was infused as in study III together with glucose to clamp PG concentration at $\simeq 130 \mathrm{mg} /$ $\mathrm{dl}$ from -120 to $0 \mathrm{~min}$. In study $\mathrm{V}$, to assess the effects of absence of the beta cells on the alpha cell response to insulin-mediated hypoglycemia, study I was carried out in type I diabetic subjects. In study VI, to assess the effects of antecedent hyperinsulinemia on the alpha cell responses to hypoglycemia in absence of beta cell function, study II was carried out in the diabetic subjects.

All studies began between 9:00 and 10:00 a.m. After an overnight fast, the subjects were placed at bed rest at least $1 \mathrm{~h}$ before studies and were maintained supine thereafter. Contralateral arm veins were cannulated with 18-gauge catheters: one, a wrist vein, was used for continuous blood withdrawal by a biostator monitor (Life Science Instruments Div., Miles Laboratories Inc., Elkhart, IN), which was used solely for constant blood glucose monitoring; the other, an antecubital vein, was used for infusion of insulin and glucose via separate Harvard pumps (model 2681, Harvard Apparatus Co., Inc., South Natick, MA). In addition, a hand vein was cannulated in retrograde fashion with a 21 -gauge butterfly needle; both the wrist vein (biostator monitor) and the hand vein were

1. Abbreviations used in this paper: AUC, area under the curves; cv, coefficient of variation; FIRI, free immunoreactive insulin; IDDM, insulin-dependent diabetes mellitus; PG, plasma glucose. maintained at $70^{\circ} \mathrm{C}$ in a thermoregulated box. The hand vein was used for intermittent sampling of arterialized venous blood (11) for determination of PG concentration every $2.5 \mathrm{~min}$ and hormone concentrations at 10-30-min intervals; the values of the PG concentrations were used to recalibrate the biostator to permit clamping at arterial glucose concentrations. The necessary adjustments in the glucose infusion rate were made empirically by altering the setting of the Harvard pumps based on the changes in the arterialized-venous PG concentrations (12). In the diabetic subjects, any intermediate or long-acting insulin was terminated at least $60 \mathrm{~h}$ before the studies and only regular insulin was given at each meal. On the night before each study, the diabetic subjects received a continuous intravenous infusion of insulin to maintain fasting PG concentration in the normal range, as previously described (13).

All reagents were prepared on the morning of each experiment. Insulin (Actrapid MC U-40, Novo Industries, Copenhagen) was dissolved in $0.9 \% \mathrm{NaCl}$ at a final dilution of $\simeq 0.8 \mathrm{U} / \mathrm{ml}$ containing $1 \mathrm{ml}$ of the subject's own blood/25 ml infusate. Glucose was administered as a $33 \%$ solution. In the clamp studies, insulin and glucose were given with a carrier infusion of $0.9 \% \mathrm{NaCl}(0.5 \mathrm{ml} / \mathrm{min})$ containing $\mathrm{K}^{+}(0.26 \mathrm{meq} /$ $\mathrm{ml})$ and $\mathrm{PO}_{4}^{--}(0.18 \mathrm{meq} / \mathrm{ml})$ to prevent hypokalemia and hypophosphatemia (12).

Arterialized blood samples $(0.3 \mathrm{ml})$ were collected at 2.5 -min intervals in heparinized microtubes and immediately centrifuged for determination of PG concentration by means of a Beckman glucose analyzer (Beckman Instruments, Inc., Fullerton, CA). Samples for plasma insulin, glucagon, and C-peptide were collected at 10-30-min intervals in iced tubes in which $0.2 \mathrm{ml} 10 \%$ EDTA- $\mathrm{Na}_{2}$ solution and $500 \mathrm{U}$ of the kallikrein inhibitor aprotinin per milliliter blood were added, and centrifuged at the end of each experiment. The resultant plasma was stored at $-20^{\circ} \mathrm{C}$ until radioimmunoassay. Free plasma insulin (14) (henceforth referred to as insulin), and C-peptide (15) were determined after plasma extraction with polyethylene glycol in diabetic and normal subjects. Plasma glucagon was determined as previously described using antibody $30 \mathrm{~K}$ (16).

Statistical methods and calculations. Data in text and figures are given as mean \pm SEM. Statistical analysis was performed using paired and, when appropriate, unpaired $t$ tests. The areas under the curves (AUC) of plasma responses of glucagon were calculated between time 0 and time 120. Insulin secretory rate was calculated from changes in plasma C-peptide concentrations using equations derived from a twocompartment model. A distribution space for C-peptide of $80 \mathrm{ml} / \mathrm{kg}$ was used instead of $41 \mathrm{ml} / \mathrm{kg}$ as originally proposed (17), since analysis of the data (18) from which the fractional disappearance rates for C-peptide were obtained for the model yielded a distribution space of $80 \mathrm{ml} / \mathrm{kg}$.

\section{Results}

Effects of antecedent euglycemic suppression of beta cell function by insulin on alpha cell response to hypoglycemia (studies I and II, Fig. 1). In study I (Fig. 1, control study), in which insulin alone was infused for $1 \mathrm{~h}, \mathrm{PG}$ concentration decreased to a nadir of $53 \pm 3 \mathrm{mg} / \mathrm{dl}$ at $45 \mathrm{~min}$. Plasma glucagon peaked at 70 $\min (247 \pm 18 \mathrm{pg} / \mathrm{ml}, P<0.001$ vs. base line $92 \pm 5 \mathrm{pg} / \mathrm{ml})$, i.e. at the time at which plasma $C$-peptide concentration had reached its nadir $(0.13 \pm 0.02 \mathrm{mg} / \mathrm{ml}, P<0.01$ vs. base line $1 \pm 0.08 \mathrm{ng} /$ $\mathrm{ml}$ ), reflecting a virtual arrest of beta cell secretion (Table I).

In study II (Fig. 1, clamp study), during the hyperinsulinemiceuglycemic clamp (plasma insulin $63 \pm 1.5 \mu \mathrm{U} / \mathrm{ml}$, PG 93 \pm 1.2 


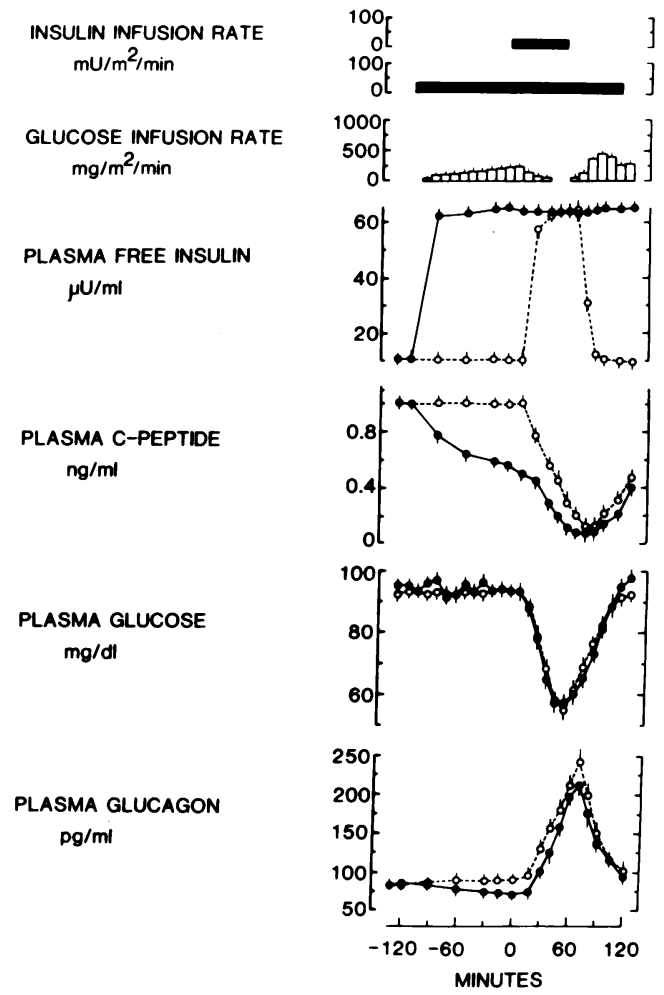

Figure 1. Responses of plasma insulin, C-peptide, glucose, and glucagon to an intravenous infusion of insulin alone $\left(30 \mathrm{mU} / \mathrm{m}^{2} \cdot \mathrm{min}\right)$ for $60 \mathrm{~min}$ (open circles, control study, study I) or to an insulin infusion from -120 to $120 \mathrm{~min}$ in combination with variable glucose (filled circles, clamp study, study II) in seven normal volunteers. $\mathrm{mg} / \mathrm{dl}$, coefficient of variation [cv] $3.5 \pm 0.1 \%$ ), the concentration of plasma C-peptide declined from $0.99 \pm 0.05 \mathrm{ng} / \mathrm{ml}$ at -120 min to $0.51 \pm 0.04 \mathrm{ng} / \mathrm{ml}$ at $0 \mathrm{~min}$, which corresponded to a decrease in endogenous insulin secretion from $13.5 \pm 0.2$ to $6.3 \pm 2.3 \mathrm{mU} / \mathrm{min}(P<0.05$, Table I), before the hypoglycemic period began. Plasma glucagon concentration was suppressed in this portion of the study by hyperinsulinemia $(87 \pm 3 \mathrm{pg} / \mathrm{ml}$ at $-120 \mathrm{~min}$ vs. $74 \pm 5 \mathrm{pg} / \mathrm{ml}$ at $0 \mathrm{~min}, P<0.001)$. Subsequently, when hypoglycemia was permitted to supervene as in study I by variable glucose infusion, plasma glucagon rose as in study I. Thus, although the beta cell secretory activity had been suppressed by $\simeq 50 \%$ before hypoglycemia in study II, the plasma glucagon responses were similar to those of study $I$ in which the endogenous insulin secretion had not been manipulated (AUC $7.2 \pm 0.5$ vs. $7.5 \pm 0.4 \mathrm{ng} / \mathrm{ml} \cdot 120 \mathrm{~min}$, study II and I, respectively, $P=$ NS).

Effects of more marked hyperinsulinemic suppression of beta cell function on alpha cell responses (study III, Fig. 2). Plasma insulin was maintained at $147 \pm 0.3 \mu \mathrm{U} / \mathrm{ml}$ throughout the study and PG concentration was clamped at $94 \pm 1 \mathrm{mg} / \mathrm{dl} \mathrm{(cv}$ $3.3 \pm 0.2 \%$ ), from -120 to $0 \mathrm{~min}$. The plasma concentration of C-peptide decreased from a base line of $1.03 \pm 0.07 \mathrm{ng} / \mathrm{ml}$ to $0.29 \pm 0.02 \mathrm{ng} / \mathrm{ml}$ at $0 \mathrm{~min}$. This represented an $\simeq 85 \%$ suppression of endogenous insulin secretion, from $14 \pm 0.3$ to $2.4 \pm 0.1$ $\mathrm{mU} / \mathrm{min}(P<0.05$, Table $\mathrm{I})$ before the hypoglycemia. Plasma glucagon was again suppressed below basal levels during this portion of the study $(98 \pm 4 \mathrm{pg} / \mathrm{ml}$ at $-120 \mathrm{~min}$ vs. $71 \pm 5 \mathrm{pg} /$ $\mathrm{ml}$ at $0 \mathrm{~min}, P<0.05$ ). When hypoglycemia was allowed to occur as in study $\mathrm{I}$, the plasma glucagon response was comparable to study I (AUC $7.6 \pm 0.6$ vs. $7.5 \pm 0.4 \mathrm{ng} / \mathrm{ml} \cdot 120 \mathrm{~min}, P=\mathrm{NS}$ ).

Effects of hyperglycemic stimulation of beta cell function

Table I. Rates of Endogenous Insulin Secretion (mU/min) Calculated Based on Modelling of Plasma C-Peptide Data (17) in Normal Subjects (studies I-IV) and in Insulin-dependent Diabetic Subjects (studies V and VI)

\begin{tabular}{lccccccccccccccccc}
\hline Minutes & -120 & -90 & -60 & -30 & -15 & 0 & 15 & 30 & 40 & 50 & 60 & 70 & 80 & 90 & 105 & 120 \\
\hline Study I & 13.5 & 14.2 & 14.4 & 14.1 & 13.8 & 14 & $3.7^{*}$ & $1.2^{*}$ & 0 & 0 & 0 & 0 & $0.7^{*}$ & $3.6^{*}$ & $8^{*}$ & $11.8^{*}$ \\
& \pm 0.3 & \pm 0.2 & \pm 0.3 & \pm 0.2 & \pm 0.3 & \pm 0.3 & \pm 0.3 & \pm 0.1 & - & - & - & - & \pm 0.1 & \pm 0.2 & \pm 0.2 & \pm 0.3 \\
Study II & 13.5 & $9.1^{*}$ & $6.8^{*}$ & $6.8^{*}$ & $6.9^{*}$ & $6.3^{*}$ & $2.8^{*}$ & 0 & 0 & 0 & 0 & 0 & $1.7^{*}$ & $3.5^{*}$ & $5.8^{*}$ & $9.7^{*}$ \\
& \pm 0.2 & \pm 0.2 & \pm 0.2 & \pm 0.2 & \pm 0.1 & \pm 0.2 & \pm 0.1 & - & - & - & - & - & \pm 0.1 & \pm 0.1 & \pm 0.1 & \pm 0.1 \\
Study III & 14 & $6.2^{*}$ & $4.3^{*}$ & $4.2^{*}$ & $4.1^{*}$ & $2.4^{*}$ & 0 & 0 & 0 & 0 & 0 & 0 & $1.2^{*}$ & $2.3^{*}$ & $4.9^{*}$ & $8.1^{*}$ \\
& \pm 0.3 & \pm 0.2 & \pm 0.2 & \pm 0.3 & \pm 0.2 & \pm 0.1 & - & - & - & - & - & - & \pm 0.1 & \pm 0.1 & \pm 0.1 & \pm 0.1 \\
Study IV & 13.9 & $22.8^{*}$ & $23.2^{*}$ & 24.2 & $25.1^{*}$ & $26.3^{*}$ & $7.3^{*}$ & 0 & 0 & 0 & 0 & 0 & 0 & 0 & $4.3^{*}$ & $10.1^{*}$ \\
& \pm 0.2 & \pm 0.6 & \pm 0.4 & \pm 0.4 & \pm 0.7 & \pm 0.7 & \pm 0.2 & - & - & - & - & - & - & - & \pm 0.1 & \pm 0.2 \\
Study V & 0.8 & 0.7 & 1 & 0.8 & 1.1 & 0.8 & 0.9 & 0.7 & 1.1 & 0.9 & 0.8 & 0.7 & 0.8 & 1 & 1.4 & 0.9 \\
& \pm 0.1 & \pm 0.2 & \pm 0.5 & \pm 0.2 & \pm 0.4 & \pm 0.3 & \pm 0.3 & \pm 0.2 & \pm 0.5 & \pm 0.3 & \pm 0.2 & \pm 0.2 & \pm 0.2 & \pm 0.2 & \pm 0.3 & \pm 0.2 \\
Study VI & 0.6 & 0.6 & 0.8 & 0.6 & 0.8 & 1.1 & 0.7 & 0.6 & 0.9 & 0.8 & 0.7 & 0.9 & 0.6 & 0.8 & 1 & 0.7 \\
& \pm 0.3 & \pm 0.4 & \pm 0.2 & \pm 0.3 & \pm 0.2 & \pm 0.3 & \pm 0.3 & \pm 0.3 & \pm 0.2 & \pm 0.1 & \pm 0.2 & \pm 0.3 & \pm 0.2 & \pm 0.2 & \pm 0.2 & \pm 0.3 \\
\hline
\end{tabular}

\footnotetext{
$* P<0.05$ vs. $-120 \mathrm{~min}$.
} 


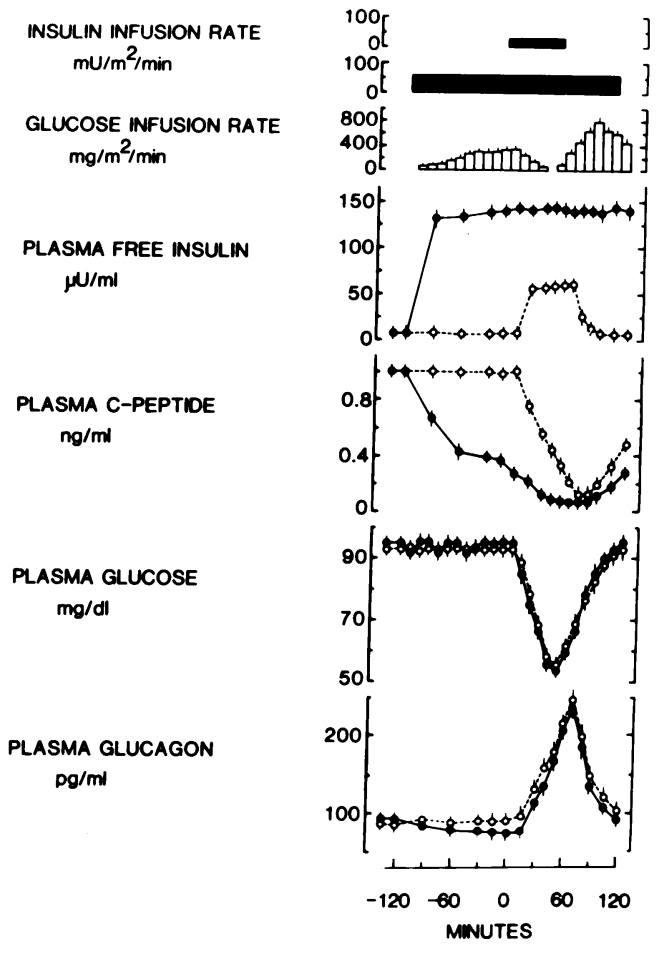

Figure 2. Effects of more marked suppression of beta cell secretory activity by an hyperinsulinemic-euglycemic clamp (insulin $60 \mathrm{mU} /$ $\mathrm{m}^{2} \cdot \mathrm{min}+$ variable glucose) on the alpha-cell responses to hypoglycemia in seven normal volunteers (full circles, clamp study, study III).

upon alpha cell responses (study IV, Fig. 3). In these experiments, plasma insulin concentration was increased at the same levels as in study III, but PG concentration was initially clamped at $132 \pm 2 \mathrm{mg} / \mathrm{dl}$ (cv $4.6 \pm 0.2 \%$ ). Despite hyperinsulinemia, the plasma concentration of C-peptide increased from $1.02 \pm 0.09$ $\mathrm{ng} / \mathrm{ml}$ at $-120 \mathrm{~min}$ to $1.76 \pm 0.21 \mathrm{ng} / \mathrm{ml}$ at $0 \mathrm{~min}$, which corresponded to $a \simeq 90 \%$ increase in endogenous insulin secretion (Table I). When hypoglycemia was permitted to occur, the plasma glucagon responses were comparable to those of study I (AUC $8.2 \pm 0.6$ vs. $7.5 \pm 0.4, P=\mathrm{NS}$ ).

Effects of absence of beta cell function on the alpha cell responses to hypoglycemia (studies V and VI, Fig. 4). When hypoglycemia was induced in C-peptide negative patients with insulin-dependent diabetes mellitus (IDDM) (study V), the plasma glucose decrease, nadir, and recovery were virtually superimposable upon those of normal subjects in study I. Despite the absence of detectable secretion of endogenous insulin in the diabetic subjects (Table I), the plasma glucagon response to hypoglycemia was virtually identical to that of the normal subjects (AUC, $7.5 \pm 0.6$ vs. $7.5 \pm 0.4 \mathrm{ng} / \mathrm{ml} \cdot 120 \mathrm{~min}, P=\mathrm{NS}$ ). In addition, when $2 \mathrm{~h}$ of more marked hyperinsulinemia preceded hypoglycemia (study VI), the response of plasma glucagon was similar to that of study $\mathrm{V}$ in which plasma insulin concentrations remained at base line before hypoglycemia (AUC, $8 \pm 0.5$ vs. $7.5 \pm 0.6 \mathrm{ng} / \mathrm{ml} \cdot 120 \mathrm{~min}, P=\mathrm{NS}$ ).

\section{Discussion}

Defense against hypoglycemia is essential to survival. It involves both the prevention of hypoglycemia and its correction, if it should occur. This study has addressed the mechanisms by which insulin-induced hypoglycemia is corrected in nondiabetic and type I diabetic subjects.

At present, the individual role of changes in PG and systemic and intraislet insulin concentration upon the plasma glucagon secretion during insulin-induced hypoglycemia is not established. Although several in vitro (19-21) and in vivo (22-24) studies have suggested that changes in glucagon secretion in response to changes in PG concentration do not necessarily require reciprocal changes in insulin secretion, insulin appears to be a potent inhibitor of glucagon secretion (8).

It had been hypothesized (9) that plasma glucagon response, the first line of defense against hypoglycemia (25), is secondary to a fall in the normally very high intraislet levels of insulin. Despite exogenous hyperinsulinemia induced peripherally, a net decline in intraislet insulin would follow the reduced local

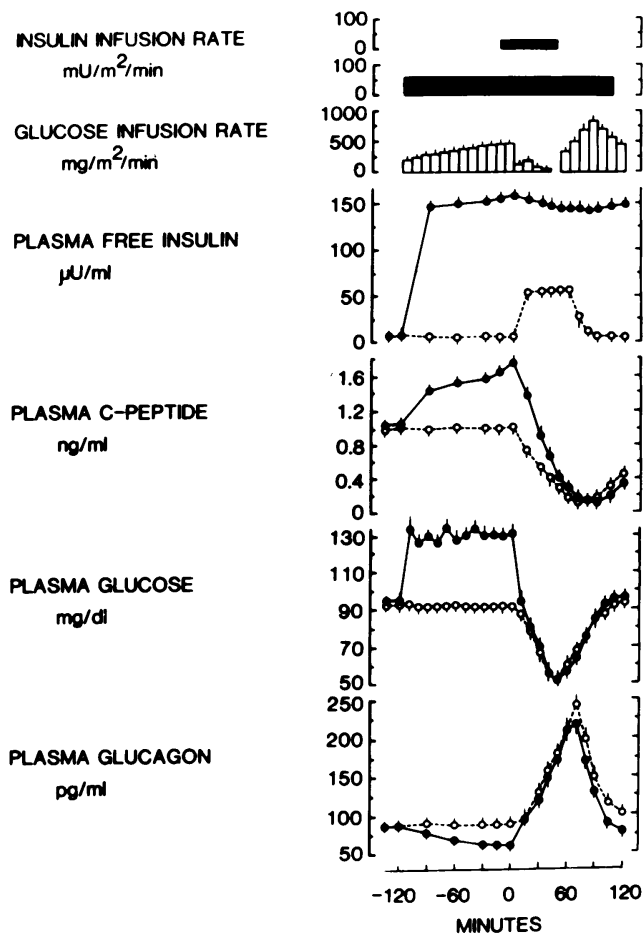

Figure 3. Effects of combined suppression and stimulation of betacell secretory activity by a hyperinsulinemic-hyperglycemic clamp (insulin $60 \mathrm{mU} / \mathrm{m}^{2} \cdot \min +$ variable glucose) on the alpha-cell responses to hypoglycemia in seven normal volunteers (filled circles, clamp study, study IV). 


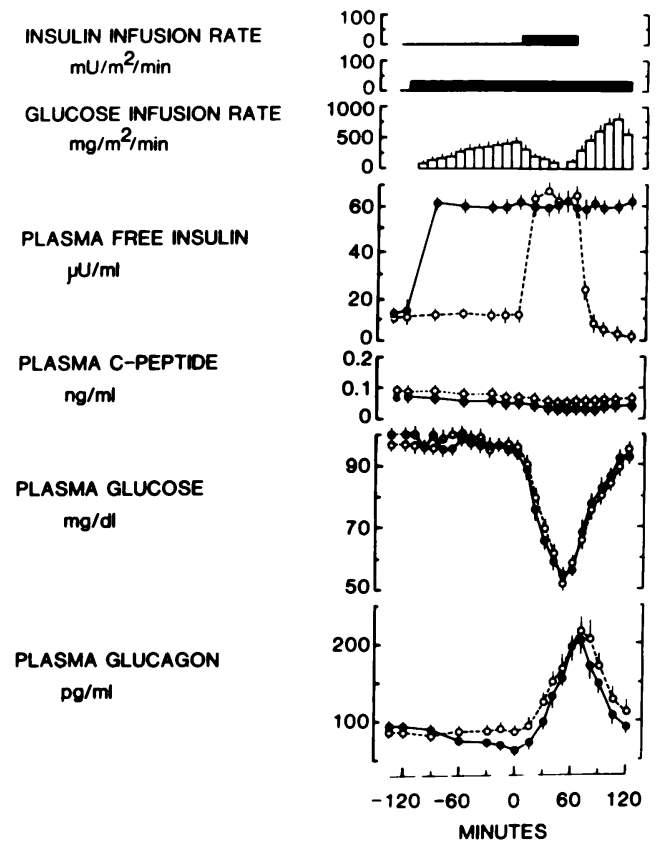

Figure 4. Responses of plasma insulin, C-peptide, glucose, and glucagon to an intravenous infusion of insulin alone $\left(30 \mathrm{mU} / \mathrm{m}^{2} \cdot \mathrm{min}\right)$ for 60 min (open circles, control study, study V) or from -120 to 120 min in combination with variable glucose (filled circles, clamp study, study VI) in five insulin-dependent diabetic subjects.

endogenous insulin levels during hypoglycemia. This would disinhibit glucagon secretion. Because of the lack of endogenous insulin secretion, type I diabetic subjects would, in contrast, experience a net rise in intraislet insulin levels during induction of hypoglycemia. This might account for their impaired plasma glucagon response and thus their vulnerability to hypoglycemia.

This study refutes the foregoing hypothesis with respect to correction of insulin-induced hypoglycemia. It shows, first, that in normal subjects, the plasma glucagon responses to insulininduced hypoglycemia are not dependent upon the antecedent level of endogenous insulin secretion and arterial insulin concentration. Second, it demonstrates that subjects with IDDM of recent onset who lack beta cell function may have a normal response of plasma glucagon to hypoglycemia, thus disputing the view that a blunted plasma glucagon response to hypoglycemia is present whenever the beta cell function is lost and is secondary to that loss (26). Finally, it suggests that if there is a loss of glucoreception by the alpha cell $(6,27)$, this loss does not necessarily occur in an early stage of $\operatorname{IDDM}(6,27)$.

While beta cell function does not seem to play a central role in the glucagon response to insulin-induced hypoglycemia, it is apparently important in the glucagon responses to nonglucose secretagogues in a euglycemic setting (28-30). It may be that whenever glucose availability is endangered, as in experimentally induced hypoglycemia, insulin's inhibitory action upon glucagon secretion (8) becomes ineffective and the hypoglycemia itself takes control of alpha cell activity either directly or via other possible mechanisms, so as to guarantee an effective glucagon response and restoration of euglycemia. This is analogous to the loss of glucagon's insulin-stimulating activity during hypoglycemia (31).

In the present experiments, the plasma glucagon responses to hypoglycemia were remarkably comparable from study to study, regardless of duration and magnitude of the acute increase in plasma insulin levels before and during hypoglycemia. In addition, the plasma glucagon responses to hypoglycemia were normal in insulin-dependent diabetic subjects despite hyperinsulinemia comparable to levels observed during exogenous insulin therapy (32). The alpha cell responses in these subjects were not blunted by the acute additional increase in plasma insulin levels in the clamp studies. Thus, it is concluded that changes in arterial plasma insulin concentration do not govern the alpha cell responses to insulin-induced hypoglycemia and that factors other than hyperinsulinemia (33) must be responsible for the progressive loss of glucagon responses to hypoglycemia in insulin-dependent diabetic subjects (34).

In conclusion, the present study demonstrates that plasma glucagon responses during insulin-induced hypoglycemia are independent of endogenous insulin secretion and arterial insulin concentration in normal man and also independent of beta cell failure and arterial insulin concentrations in subjects with diabetes mellitus of short duration. Thus, it is unlikely that suppression of insulin release during hypoglycemia modulates plasma glucagon responses in normal man and that lack of a decrease in intraislet insulin concentration is responsible for the lack of a plasma glucagon response to hypoglycemia in subjects with type I diabetes mellitus.

\section{Acknowledgments}

The superb editorial assistance of Mrs. Marylee Campion and Mrs. Georgina Hoddle Stoppini is gratefully acknowledged.

This work was supported by the Consiglio Nazionale delle Ricerche (C.N.R. Finalized Project: Complications of Diabetes-Ob.46), by a Veterans Administration Institutional Research Support grant (549-800001 ) and by a grant from the U. S. Public Health Service (AM02700-16).

\section{References}

1. Cryer, P. E. 1981. Glucose counterregulation in man. Diabetes. 30:261-264.

2. Gerich, J., J. Davis, M. Lorenzi, R. Rizza, J. Karam, S. Lewis, R. Kaplan, T. Schultz, and P. Cryer. 1979. Hormonal mechanisms of recovery from insulin-induced hypoglycemia in man. Am. J. Physiol. 236:380E-385E.

3. Rizza, R. A., P. E. Cryer, and J. E. Gerich. 1979. Role of glucagon, catecholamines, and growth hormone in human glucose counterregulation: effects of somatostatin and combined $\alpha$-and $\beta$-adrenergic blockade on plasma glucose recovery and glucose flux rates following insulininduced hypoglycemia. J. Clin. Invest. 64:62-71. 
4. Tse, T. F., W. E. Clutter, S. D. Shah, J. P. Miller, and P. E. Cryer. 1983. Neuroendocrine responses to glucose ingestion in man: specificity, temporal relationships and quantitative aspects. J. Clin. Invest. 72:270 277.

5. Tse, T. F., W. E. Clutter, S. D. Shah, and P. E. Cryer. 1983. The mechanisms of postprandial glucose counterregulation in man: physiologic roles of glucagon and epinephrine vis-a-vis insulin in the prevention of hypoglycemia late after glucose ingestion. J. Clin. Invest. 72:278286.

6. Gerich, J. E., M. Langlois, C. Noacco, J. A. Karam, and P. H. Forsham. 1973. Lack of glucagon response to hypoglycemia in diabetics: evidence for an intrinsic pancreatic alpha-cell defect. Science (Wash. DC). 182:171-173.

7. Deaths among patients using continuous subcutaneous insulin infusion pumps. 1982. Centers for Disease Control. Morbidity and Mortality Weekly Report. 31:80-81.

8. Samols, E., J. M. Tyler, and V. Marks. 1972. Glucagon-insulin relationships. In Glucagon: Molecular Physiology, Clinical and Therapeutic Implications. P. J. Lefebvre and R. H. Unger, editors. Pergamon Press, Inc., Elmsford, NY. 151-173.

9. Unger, R. H. 1983. Insulin-glucagon relationships in the defense against hypoglycemia. Diabetes. 32:575-583.

10. Samols, E., G. Weir, and S. Bonner-Weir. 1983. Intra-islet insulinglucagon-somatostatin relationships. In Handbook of Pharmacology. Glucagon II. P. J. Lefebvre, editor. Springer-Verlag Books, London. 133-173.

11. McGuire, E., J. Helderman, J. Tobin, R. Andes, and M. Berman. 1976. Effects of arterial versus venous sampling on analysis of glucose kinetics in man. J. Appl. Physiol. 41:565-573.

12. Rizza, R. A., L. Mandarino, and J. Gerich. 1981. Dose-response characteristics for the effects of insulin on production, and utilization of glucose in man. Am. J. Physiol. 240:E630-E639.

13. Bolli, G., P. De Feo, P. Compagnucci, M. G. Cartechini, G. Angeletti, F. Santeusanio, and P. Brunetti. 1982. Important role of adrenergic mechanisms in acute glucose counterregulation following insulininduced hypoglycemia in type I diabetes. Evidence for an effect mediated by beta-adrenoreceptors. Diabetes. 31:641-647.

14. Kuzuya, H., P. M. Blix, D. L. Horwitz, D. F. Steiner, and A. H. Rubenstein. 1977. Determination of free and total insulin and C-peptide in insulin-treated diabetics. Diabetes. 26:22-29.

15. Faber, O. K., J. Markussen, U. K. Naithani, and C. Binder. 1976. Production of antisera to synthetic benzyloxycarnonyl-C-peptide of human pro-insulin. Hoppe-Seyler's Z. Physiol. Chem. 357:751-757.

16. Faloona, G., and R. H. Unger. 1974. Glucagon. In Methods of Hormone Radioimmunoassay. B. Jaffe and H. Behrman, editors. Academic Press, Inc., New York. 317-330.

17. Eaton, R. P., R. C. Allen, D. S. Schade, K. M. Erickson, and J. Standfer. 1980. Prehepatic insulin production in man: kinetic analysis using peripheral connecting peptide behaviour. J. Clin. Endocrinol. Metab. 51:520-528.

18. Faber, O. K., C. Hagen, C. Binder, J. Markussen, U. K. Naithani, P. M. Blix, H. Kuzuya, D. L. Horwitz, and A. H. Rubenstein. 1978 Kinetics of human connecting peptide in normal and diabetic subjects. J. Clin. Invest. 62:197-203.

19. Pagliara, A. S., S. N. Stillings, B. Hover, D. M. Martin, and F. M. Matschinsky. 1974. Glucose modulation of amino acid-induced glucagon and insulin release in the isolated perfused rat pancreas. $J$. Clin. Invest. 54:819-832.

20. Gerich, J. E., M. A. Charles, and G. M. Grodsky. 1974. Char- acterization of the effects of arginine and glucose on glucagon and insulin release from the perfused rat pancreas. J. Clin. Invest. 54:833-841.

21. Sorenson, R. L., and R. P. Elde. 1983. Dissociation of glucose stimulation of somatostatin and insulin release from glucose inhibition of glucagon release in the isolated perfused rat pancreas. Diabetes. 32:561567.

22. Santiago, J. V., W. L. Clarke, S. D. Shah, and P. E. Cryer. 1980. Epinephrine, norepinephrine, glucagon and growth hormone release in association with physiological decrements in the plasma glucose concentration in normal and diabetic man. J. Clin. Endocrinol. Metab. 51:877-883.

23. Bolli, G., P. De Feo, P. Compagnucci, M. G. Cartechini, G. Angeletti, F. Santeusanio, P. Brunetti, and J. E. Gerich. 1983. Abnorma glucose counterregulation in insulin-dependent diabetes mellitus. Interaction of anti-insulin antibodies and impaired glucagon and epinephrine secretion. Diabetes. 32:134-141.

24. De Feo, P., G. Bolli, G. Perriello, S. De Cosmo, P. Compagnucci, G. Angeletti, F. Santeusanio, J. E. Gerich, and P. Brunetti. 1983. The adrenergic contribution to glucose counterregulation in Type I diabetes mellitus: dependency on A-cell function and mediation through beta ${ }_{2}-$ adrenergic receptors. Diabetes. 32:887-893.

25. Gerich, J. E. Glucagon as a counterregulatory hormone. 1983. In Handbook of Experimental Pharmacology. Glucagon II. P. J. Lefebvre, editor. Springer-Verlag Books, London. 275-295.

26. Madsbad, S., J. Hilsted, T. Krarup, L. Sestof, N. J. Christensen, O. K. Faber, and B. Tronier. 1982. Hormonal, metabolic and cardiovascular responses to hypoglycemia in type I (insulin-dependent) diabetes with and without residual B-cell function. Diabetologia. 23:499-503.

27. Gerich, J. E., R. A. Rizza, C. A. Verdonk, J. M. Miles, and M. W. Haymond. 1981. Role of counterregulatory hormones in diabetes mellitus. In Etiology and Pathogenesis of Insulin-dependent Diabetes Mellitus. J. M. Martin, R. M. Ehrlich, and F. J. Holland, editors. New York. 125-140.

28. Asplin, C. M., T. L. Paquette, and J. P. Palmer. 1981. In vivo inhibition of glucagon secretion by paracrine beta cell activity in man. J. Clin. Invest. 68:314-318.

29. Pfeifer, M. A., J. C. Beard, J. B. Halter, R. Judzewitsch, J. D. Best, and D. Porte, Jr. 1983. Suppression of glucagon secretion during a tolbutamide infusion in normal and noninsulin-dependent diabetic subjects. J. Clin. Endocrinol. Metab. 56:586-591.

30. Asplin, C., P. Raghu, T. Dornan, and J. Palmer. 1983. Glucose regulation of glucagon secretion independent of B cell activity. Metab. Clin. Exp. 32:292-295.

31. Goldfine, I., E. Cerasi, and R. Luft. 1972. Glucagon stimulation of insulin release in man: inhibition during hypoglycemia. J. Clin. Endocrinol. Metab. 35:312-315.

32. Rizza, R. A., J. E. Gerich, M. W. Haymond, R. E. Westland, L. D. Hall, A. H. Clemens, and F. J. Service. 1980. Control of blood sugar in insulin-dependent diabetes: comparison of an artificial endocrine pancreas, continuous subcutaneous insulin infusion and intensified conventional therapy. N. Engl. J. Med. 303:1313-1318.

33. Unger, R. H. 1982. Special comment: meticulous control of diabetes: benefits, risks and precautions. Diabetes. 31:479-483.

34. Bolli, G., G. Calabrese, P. De Feo, P. Compagnucci, G. Zega, G. Angeletti, M. G. Cartechini, F. Santeusanio, and P. Brunetti. 1982. Lack of glucagon response in glucose-counterregulation in type I (insulindependent) diabetics: absence of recovery after prolonged optimal insulin therapy. Diabetologia. 22:100-105. 